\title{
Poet-translators as double link in the global literary system ${ }^{1}$ Ana Mata Buil
}

\author{
Universitat Pompeu Fabra, Barcelona
}

\begin{abstract}
This paper - based on the diachronic and international study of American Modernism and its translation into Spanish - aims to analyze the complementary role of poet-translators as a double link in the global literary system. On the one hand, when translating other authors, poet-translators introduce them to a new audience. On the other hand, their translations complement their own poetic creations. While translating poetry, poet-translators assimilate the original poet's style and images, which will later filter in their own poetic works. But, at the same time, these literary agents - consciously or unconsciously - introduce their own style marks into their translations. In order to illustrate the analysis, those people whose role as poet-translators stands out have been chosen among all the translators of Modernist poets into Spanish. Adding to this, some examples of Modernist poets who were also translators are commented on-Yvor Winters, Marianne Moore, Langston Hughes, Hilda Doolittle, and Ezra Pound.
\end{abstract}

\section{KEYWORDS}

poet-translators North-American Modernism global literary system

poetry translation Spanish translation

\footnotetext{
${ }^{1}$ The final version of this paper was published in Translation and Interpreting Studies 11:3 (2016), John Benjamins Publishing Company, 398-415. ISSN 1932-2798 / E-ISSN 1876-2700
} 


\section{Introduction}

The aim of this article is to analyze the phenomenon of poet-translators as double links in the global literary system. To illustrate the analysis, several examples will be given of poets who have translated the work of American Modernist authors into Spanish, as well as examples of Modernist poets who have been translators themselves. The idea of integrating "translated literature" into the literary polysystem of the target culture - as expressed by Itamar Even-Zohar (1990) — will be one of the cornerstones of this study. Even though "translated literature" has not been given much room in theoretical studies until the last few decades, its importance inside the polysystem can sometimes be crucial, especially when "it participates actively in shaping the center of the polysystem. In such a situation it is by and large and integral part of innovatory forces, and as such likely to be identified with major events in literary history" (Even-Zohar 1999, 46-47). As we will see in what followings, that is the case when translated poetry helps adopting new styles, elaborating the new repertoire.

My understanding of the poet-translator is related to Sela-Sheffy's description of certain translators who "claim the position of ambassadors of "world cultures' rather than of gatekeepers, taking the task of opening up the local culture and enriching its language and forms of expression" (Sela-Sheffy 2005, 8). I would say the double role that poet-translators play within the literary polysystem - as authors of new creations, as well as translators of poems written by others - often allows them to act as "ambassadors." While each of these two roles can have more or less weight inside the target literary polysystem, both will influence the symbolic capital obtained by poet-translators, and therefore, their impact on readers and critics.

This analysis, however, will not be limited to the study of Anglo-Saxon and Spanish cultures in an isolated way. On the contrary, I would like to relate these polysystems with a global literary system, following the lead of researchers on the sociology of translation, such as Johan Heilbron (1999) and Gisele Sapiro (2009). “A world-system of translation,” Heilbron argues, "is best conceived as a transnational cultural field, in Pierre Bourdieu's sense, or as an emerging cultural world-system in Abram de Swaan's term” (Heilbron 1999, 432). In my opinion, taking world literature as a common good has advantages both for comparative literature and for translation studies, since it enhances the translation role in the development of the global literary system. As for Sapiro’s contribution, which also stems from Bourdieu's theories, it is useful for this study for two reasons - it reflects on the center-periphery movements 
made possible by translations, and it insists on the economic nature of cultural exchanges, whether they follow "la loi du marché," the law of the market, or "l'économie des biens symboliques," the economy of symbolic goods (Sapiro 2009, 252).

\section{A comparative over-view of the reception of North-American Modernist poets}

This topic is inserted in a broader study dedicated to the translation and reception of Modernist poetry in English and Spanish, based on an international and diachronic analysis of a corpus containing 28 American Modernist poets. ${ }^{2}$ We refer here to Modernism in a broad, "polyphonic," ${ }^{3}$ non-restrictive sense, which allows a dialogue between the different co-existing tendencies. The selected poets are W. H. Auden, Elizabeth Bishop, Louise Bogan, Hart Crane, E. E. Cummings, Hilda Doolittle, T. S. Eliot, Robert Frost, Langston Hughes, Robinson Jeffers, Weldon Kees, Archibald MacLeish, Edna St. Vincent Millay, Marianne Moore, Robert Penn Warren, Ezra Pound, Laura Riding, Charles Reznikoff, Edwin Arlington Robinson, Theodore Roethke, Muriel Rukeyser, Carl Sandburg, Gertrude Stein, Wallace Stevens, Allen Tate, William Carlos Williams, Yvor Winter, and Elinor Wylie.

According to the information gathered so far, there are up to 1,330 different editions ${ }^{4}$ of the poetic works of these 28 poets published in hard copy in English between 1912 and 2012. ${ }^{5}$ As can be expected, the number of editions is distributed in an uneven manner among the poets.

\footnotetext{
2 The corpus is based on the comparison of the poets listed in The Poetry Anthology. 1912-2002 (Parisi and Young, 2002) between 1912-1941, with those appearing in The Norton Anthology of Poetry (Ferguson et al. 2004 [1970]), The Norton Anthology of Modern and Contemporary Poetry (Ramazani et al. 2003 [1973]), The Oxford Book of American Poetry (Lehman and Brehm 2006 [1976]), and Anthology of Modern American Poetry (Nelson 2000). Only those poets present in Poetry's anthology plus at least three of the other four sources have been taken into account for the study.

3 The term "polyphonic" is taken from Claudio Guillén, who applies it to comparative literature in Entre lo uno y lo diverso (2005: [1985]).

4 The term "different edition" refers here to every launching of a literary work, either in a different publishing-house, or in a different series, or else in a different format (limited edition, non-selling edition, big-circulation edition...), since each of them may have a different reception and may have added to the poet's symbolic capital in a different way.

${ }^{5}$ Data obtained from the British Library, the Library of Congress, and from bibliographical compilations dedicated to specific authors. For the purpose of this article, ebook editions will not be taken into account. In a broader study, such as the $\mathrm{PhD}$ thesis, both printed and electronic books will be compiled and analyzed, for there may be a change in the publishing tendency concerning certain authors. See Mata Buil (2016).
} 
T. S. Eliot (114 editions), Robert Frost (101 editions) and Ezra Pound (100 editions) have been published in English far more often than the others. This both reflects and enhances their symbolic capital. These three poets are followed in number of original editions by W. H. Auden (78), E. E. Cummings (68), Edna St. Vincent Millay (68), William Carlos Williams (66), and Hilda Doolittle (66). Wallace Stevens, another central figure of the Modernist movement, has had 52 different editions published in English. Such figures are important because the presence of certain poets' in Anglo-Saxon culture contrasts with their presence in the international arena.

Only 17 out of these 28 Modernist authors have had books of their poetry translated into Spanish in Spain, Mexico or Argentina, the three Spanish-speaking countries considered in this article. Restricting the Spanish editions to those countries leaves out translations made in other Latin-American countries, which may also have contributed to the introduction of American Modernism in Hispanic culture. However, the importance of the publishing industry in the countries selected, together with the cultural influence they have had throughout the century covered by the study, I feel, justifies the restriction.

The poets whose work has been translated less frequently into Spanish are the following-W. H. Auden, Elizabeth Bishop, Hart Crane, E. E. Cummings, T. S. Eliot, Robert Frost, Hilda Doolittle, Langston Hughes, Robinson Jeffers, Archibald MacLeish, Marianne Moore, Ezra Pound, Theodore Roethke, Carl Sandburg, Gertrude Stein, Wallace Stevens, and William Carlos Williams.

Out of the 1,330 works compiled in English, 992 belong to these 17 poets. Checking the data from the Mexican, Argentinian and Spanish National Libraries, as well as the ISBN database, and bibliographical works dedicated to one or some Modernist poets, a total number of 164 translated poetry books was found. Such a figure can be divided as follows - 65 original books of poetry translated into Spanish, 92 single-author translated anthologies, and only 7 editions of translated "complete poems" compilations by a particular author.

The translators who have enabled the entry of these poetic works into the global literary system have different profiles, and by no means follow a single pattern. Some are poettranslators, while others are professional translators; some are literary critics, and some scholars specialize on a particular author. There are also cases of translators who combine several of these roles. Among the different profiles there is one that could be stressed-poet-translators or 
translator-poets, depending on which mode of textual production is the more dominant. For instance, some of the poet-translators who have rendered the work of Modernist poets into Spanish are Octavio Paz, Juan Ramón Jiménez, León Felipe, Agustí Bartra, Andrés Sánchez Robayna, and Joan Margarit, as well as Dámaso Alonso, Leopoldo Panero, and Jenaro Talens.

\section{The case of Spanish and Latin-American poets translating Modernist poets}

Why is it so common that a poet translates another poet, who is at the same time the translator of someone else's work? Observation shows that there are three possible main reasons behind this phenomenon.

\subsection{Poets considered the best translators of poetry}

To begin with, this common phenomenon could be an answer to the general opinion that "only a poet can translate poetry," a kind of specificity that is not expected from any other literary translator. On the contrary, professional translators are expected to be versatile and capable of adapting to different genres and styles. The special status given to poetry by editors, critics and readers is related to the notion that the translation of poetry should be in turn a poetic composition in the target language, and not a meaning-explanation of the original. This would also relate to Even-Zohar's opinion on the prestige obtained by writer-translators: it is often "leading writers (or members of the avant-garde who are about to become leading writers) who produce the most conspicuous or appreciated translations" (Even-Zohar 1990, 47).

To some poet-translators, such as poet and translator of Latin and ancient Greek poems Josephine Balmer, poetry and translation are interwoven: "But translation or poetry, the challenge is always the same: to bring the past into the present and at the same time to recreate it afresh ... the one leads into the other and in their continued practice, the two become indivisible" (quoted in: Bassnet 2006, 194).

Spanish poet-translators Juan Malpartida and Joan Doce, co-authors of a translated selection of T. S. Eliot's poetry_La tierra baldía. Cuatro cuartetos y otros poemas. Poesía selecta (1909-1942), published in 2001 — argue that translating properly means creating new poems in the target language while keeping faithful to the original poems, which act as a starting-point. They apply the notion of re-reading and re-creation analyzed by Ruiz Casanova 
(2007) in his dissertation Anthologos: Poética de la antología poética ["Anthologos: Poetics of the Poetic Anthology"], to the anthologists who also translate their selections:

Every time we read a good translation we can hear the original poet and also a bit of the new readerfor translating is hyper-reading. We can hear Pound when translating Propertius's poems, we can hear [Claudio] Guillén when translating Valery's, and [Octavio] Paz when translating Basho's (Malpartida, and Doce 2001, 39). ${ }^{6}$

This duet is even more audible when the translation is published in a bilingual edition, an increasingly common practice. ${ }^{7}$ A bilingual lay-out is always a challenge for the translator, and more so when both versions are presented en face. Nevertheless, the comparison with the original also gives the translator the opportunity of appearing on the same level as the poet, whereas having the poems available in the source language available can help justify some translation options. The people responsible for such bilingual editions do not consider the translation as a paraphrase of the original, but as poetry. For instance, Eliot's anthologists Malpartida and Doce admit their bilingual edition is a sign of their admiration for Eliot, but claim that their purpose is not to help the reader more quickly understand the original. On the contrary, "we have tried to translate Eliot poetically. That is, to insert him in the Spanish poetic tradition" (Malpartida, and Doce 2001, 39). ${ }^{8}$

When publishers and editors want the creation by the original poet and the re-creation by the translator together in the same book, they often ask poets to translate poems or at least to "round off" the translations to make them sound more poetic. An example of this would be Elizabeth Bishop's anthology put together by translator and professor Sam Abrams (Obra poética, 2008), and co-translated by Abrams and Catalan translator Joan Margarit. In his prologue, Abrams $(2008,14)$ states his aim to be creating a bridge between cultures and introducing foreign authors into the Spanish and Catalan literary system through collaboration with other translators and poets. His "fruitful collaboration" with Joan Margarit, as he describes

\footnotetext{
6 "Siempre que leemos una buena traducción oímos al poeta original y, un poco, al nuevo lector (porque traducir es una hiperlectura). Oímos a Pound en sus traducciones de Propercio, a Guillén en las de Valéry, a Paz en las de Basho" (Malpartida, and Doce 2001, 39).

${ }^{7} \mathrm{Up}$ to this moment, 85 translated poetic anthologies have been analyzed, 48 of which (56\%) present a bilingual EnglishSpanish lay-out. This tendency has increased over the last forty years.

8 "Hemos tratado de traducir poéticamente a Eliot, es decir, insertarlo en la lengua poética española" (Malpartida and Doce 2001, 39).
} 
it, is one more step toward this goal. In turn, poet-translator Margarit, in his "Introductory essay" to Elizabeth Bishop's life and work, lists and comments on the currently available Spanish translations of Bishop. This reinforces the idea that the American poet has entered the world patrimony thanks to translation.

\subsection{Increase in symbolic capital}

The second reason that can move a poet to translate another poet is the will to win more symbolic capital through translation by association. I agree with Heilbron $(1999,432)$ that:

Cultural exchanges have a dynamic of their own which is based on a certain autonomy vis-à-vis the constraints of the world market. Instead of conceiving the cultural realm as merely derivative of the world market, it is more fruitful to view transnational cultural exchange as a relatively autonomous sphere, as an international arena with economic, political and symbolic dimensions.

The symbolic dimension is increased where poetry is concerned, for, as Sapiro (2009) states, poetry belongs to the restricted diffusion pole of global literature. And this pole follows the rules of the economy of symbolic goods. That is, the author's prestige is linked to the opinion of critics and scholars, together with the audience response to his or her poetic work, instead of the laws of profitability and mass-market. ${ }^{9}$ This distinction helps us understand why symbolic capital can have a greater impact than economic capital when deciding whether or not to translate certain poets in a particular moment in order to introduce them into the global literary system.

On the one hand, if the translated poets have a more central position inside the literary system, they can increase the symbolic capital of their poet-translators, who see their name linked to the consecrated poet. That is the case of Spanish poet, critic and translator Docealready mentioned in this article - who has translated poems by T. S. Eliot, Ted Hughes, and W. H. Auden, among others. His anthology of Eliot's poetry, co-translated with Malpartida and published in 2001, is obviously not meant to introduce Eliot to a new audience, since the first Spanish translation of Eliot's poems appeared in the late 1940s. Nevertheless, Doce and Malpartida's effort is valuable because they offer, in addition to the widely-translated The Waste

\footnotetext{
${ }^{9}$ «Le pôle de diffusion restreinte fonctionne selon les logiques propres à l'économie des biens symboliques, obéissant à des règles spécifiques d’terminées par des instances particulières (revues, associations, congrès, jurys) dans des espaces relativement autonomes des contraintes commerciales et politiques, que Pierre Bourdieu appelle des 'champs'» (Sapiro 2009, 252).
} 
Land and Four Quartets, a broad selection of lesser-translated works, including fragments of The Hollow Men and Ash-Wednesday. The selection is accompanied by a long introduction to the author by the poet-translators, in which they justify their new version as an attempt to mitigate the lack of poetry in previous translations. According to the poet-translators, the constraints imposed by the original cannot be solely to blame for the lack of poetic value in previous translations.

On the other hand, if the poet-translators enjoy higher status inside the literary system, and the poet to be translated has not yet entered the global system, the translator's symbolic capital can help introduce the poet into global literature. This is what Pascale Casanova (2001, 17) calls "capital du traducteur consecrant lui-même" ["the capital of the consecrating translators themselves"]. The desire to introduce a poet into the new literary system is even greater in translated anthologies, which aim to offer a selection of the best poems written by an author-at least in the eyes of the anthologist — and, therefore, offer a panoramic view of the author to new readers.

Among the poet-translators that consecrate other authors through a translated poetic anthology stands the famous Mexican poet, critic and diplomat Octavio Paz, Nobel Prize winner for Literature in 1990. Paz selected and translated Veinte poemas (1973) by William Carlos Williams, the first book in Spanish dedicated entirely to Williams's poetry. The symbolic capital of such a translator and the importance given to the anthology by the publishers is stated on the back cover - "The great poet and translator of poetry, Octavio Paz, renders these twenty poems into Spanish, thus creating twenty new and equally poetic pieces." The publishers also note that Paz has written "a precise and magnificent prologue, giving light both to the work and to the man, whom Paz considers 'the author of the most vivid poems in modern North-American poetry'."10 The influence that Octavio Paz has had on other poet-translators is undeniable. Many anthologists name him in their prologues, since he is considered an authority. A good opinion on

\footnotetext{
10 "Gran poeta y gran traductor de poetas, Octavio Paz trae al castellano estos veinte poemas, creando otras tantas piezas equivalentes, y además, en un prólogo conciso y rico, nos ilumina tanto la obra como la persona de aquel a quien considera 'el autor de los poemas más vivos de la poesía norteamericana moderna'.” (Veinte poemas, 1973, back cover).
} 
his part augments the symbolic capital of an author or translator and can help "consecrate" them both. $^{11}$

There are, of course, instances in which the symbolic capital of the original author and the translator are balanced. Take, for example, Eliot, the most international Modernist poet, whose symbolic capital rocketed upward after he received the Nobel Prize for Literature in 1948. Among the numerous translated anthologies dedicated to this author, we would like to focus on the translation made in Buenos Aires by a conglomerate of exiled Spanish poets and LatinAmerican poets, including Rodolfo Usigli, León Felipe, Octavio G. Barredo, B. Ortiz de Montellano, Juan Ramón Jiménez, ${ }^{12}$ Marià Manent, ${ }^{13}$ and Ángel Flores. In the mid-fifties, they contributed to an anthology called Tierra baldía y otros poemas ["The Wasted Land, and Other Poems"] (1954).

Another interesting anthology also published in Eliot's life, but in Madrid, was Poemas (1946), with versions by Dámaso Alonso, Leopoldo Panero, J. M. Muñoz Rojas, Charles D. Ley, and J. L. Cano. On the copyright page, we can read a note of thanks to the author for permission to publish the translated poems. ${ }^{14}$ This gives the edition an air of "authorized" selection. In such cases, Eliot's symbolic capital obviously contributes to that of his poet-translators, who have the honor of translating his work. However, at the same time, Eliot's own symbolic capital in Hispanic culture grows due to the translation by such popular poets.

\footnotetext{
11 According to Sapiro $(2009,254)$, the number of books "entrées dans le patrimoine universelle" by means of translation influences the perception about the symbolic capital of an author.

${ }^{12}$ Poet Juan Ramón Jiménez, who also obtained the Nobel Prize for Literature (1956), had a special relationship with AngloSaxon and Spanish poetic traditions. His trip to the United States in 1916 introduced him to American Modernism, which influenced his writing, and that of his poetic generation. Some years later he went into exile due to the Spanish Civil War-first to the United States, and then to Buenos Aires and Puerto Rico - and spent the rest of his life in America, where he was much appreciated. During his exile, Jiménez found new poetic models both in reading poets from other traditions and in translating them.

${ }^{13}$ According to D. Sam Abrams (1998), Manent considered that translation had two main purposes-improving the artistic tools of the poet-translator and enriching his or her own cultural tradition through new models (see Ruiz Casanova 2011, 101). This would relate to point 3.3 in this article, "Affinity between two poets".

14 “'Adonais” quiere agradecer públicamente a T. S. Eliot su generosidad al ceder los derechos de traducción de los poemas suyos recogidos en este volumen" (Poemas, 1946, copyright page).
} 


\subsection{Affinity between two poets}

The third and last reason that might explain why a poet becomes another poet's translator is an aesthetic affinity between them. Guillén (2005 [1985], 325) summarizes this artistic connection by quoting Poggioli, who stated that a translator is "a literary artist looking out of himself for the adequate form to the experience he or she wants to convey." ${ }^{15}$ He then offers Baudelaire's words justifying his translation of Edgar Allan Poe's poems: "Savez-vous pourquoi j'ai si patiemment traduit Poe? Parce qu'il me ressemblait." ${ }^{16}$ Susan Bassnett, on her part, comments on poettranslators:

For [Ted] Hughes, as for many poets, writing and translating were not antipathetic but rather offered different possibilities at different points in his literary career ... Frequently writers translate other people's works because those are the works they would have written themselves had they not already have been created by someone else (Bassnett 2006, 175).

According to Spanish scholar Ruiz Casanova $(2011,94)$, this would be the main reason why poets translate other poets, as part of their "aesthetic search" and their "will to complete their own lyric idiolect." ${ }^{17}$ Let us take as an example the case of Canary-Islands-based poet, critic and professor Andrés Sánchez Robayna, who is responsible for several anthologies of Wallace Stevens's work. The last of these is De la simple existencia. Antología poética (2003), a corrected version of his previous anthology Poemas (1980). Sánchez Robayna's interest in Stevens's poetry was born from stylistic affinity, nd the time dedicated by the Spanish poet to the study, translation and revision of his Spanish versions of Stevens's poems has permeated his own poetry. Sánchez Robayna shares with Williams an intellectual conception of poetry and a focus on the poem as topic for the poem.

Sánchez Robayna does not consider translation a subsidiary activity, but part of his poetic creation. For that reason, he mentions his translations, and prizes related to his translation practice — such as Spanish National Prize for Translation in 1982 - on the back covers of his own

\footnotetext{
15 "un artista literario que busca fuera de sí mismo la forma adecuada a la experiencia que desea expresar" (Claudio Guillén 2005 [1985], 325).

${ }^{16}$ Quotation taken by Guillén from Haskell Block $(1981,120)$.

17 "La idea del poeta-traductor como vía de acceso a la propia obra y como intercesión obligada de toda búsqueda estética".

“Así, y cada vez con más insistencia, la traducción poética [responde] a las necesidades individuales de completar algo más que una lengua poética, completar -y contribuir a formar-el idiolecto de un poeta”. (Ruiz Casanova 2011, 94).
} 
poetry books. This shows that his prestige as a translator adds value to his symbolic capital as a creator and links him to world literature.

\section{North-American Modernist poets and their role as translators}

So far I have talked about poet-translators who have brought North-American Modernist poets to a Spanish-speaking audience. This study would not be complete, however, without analyzing the role played by North-American Modernist authors as poet-translators, since they, too, helped to introduce foreign authors into their nativeliterary system, and consequently, into the global literary system.

Many Modernist poets published translations at some point in their literary career, mainly from Romance languages. For instance, T. S. Eliot translated St.-J. Perse's poems from French, and Marianne Moore translated La Fontaine's fables. Moore considered that translation to be as personal as any of her "original" poems. That is why she included a selection of her fables at the end of The Complete Poems of Marianne Moore, a compilation made by Moore herself in 1967. Langston Hughes translated Federico García Lorca, Nicolás Guillén, and Gabriela Mistral from the Spanish, while Yvor Winters translated both from Spanish—canonical authors such as Francisco de Quevedo and Saint Teresa of Avila—and from French-Pierre de Ronsard, Mallarmé, Verlaine and Baudelaire. Edna St. Vincent Millay also translated Baudelaire's poems, and together with George Dillon, a poet and editor of the journal Poetry, published and English translation of Baudelaire's Fleurs du Mal. The reason why Modernist poets translated Baudelaire was similar to the reason why Baudelaire had translated Poe some decades before-in order to polish their poetic voice through the translation of poets with whom they sensed an aesthetic affinity.

Adding to this, there are remarkable crossed translations between poets. We refer to cases such as that of Octavio Paz and some Modernist poets, who, translating each other, boost the symbolic capital on both sides of the relationship. The publishers of Elizabeth Bishop's anthology Obra poética (2008) note that Bishop translated Octavio Paz's poems, “who, in turn, translated several of her poems into Spanish and wrote bright pages about the meaning of 
Bishop's work."18 Paz $(1973,24)$ himself mentions in his introductory note to Williams's poetic anthology that he was impressed by Williams's English version of his poem Himno entre ruinas, and that moved him to get to know the American poet and later to translate his work. It seems clear that such "crossed translation" between poets is a mark of mutual affinity. Thanks to this activity, the double link constituted by one poet-translator in the global literary system gets attached to the double link represented by the other translated poet-translator.

Nevertheless, different authors have different conceptions of their task as translators. For some it runs parallel to their own poetic creations, whereas for others it is merely a complementary or secondary activity. In this respect, Susan Bassnet $(2006,173)$ writes, "such a distinction exists and seems to have been in operation for some time now, which has led to translation being seen as the poor relation of writing, often referred to as 'original' or 'creative' writing, and widely perceived as superior." And such a dichotomy can also be seen in bibliographical works dedicated to North-American poets, where translations made bythe poets are treated in various ways, depending on the researcher.

In the book-length bibliographies dedicated to each of these authors, I have noticed divergences in the treatment given to their own translations. Some of the compilers, like Grosvenor Powell (1983) in his annotated bibliography of Yvor Winters, list them under the title "Poetry Translations." Others make distinctions between translated poems published in magazines and collected works, from those published as a single-author book. That is the case of scholar Donald C. Dickinson (1972), who includes the chapter: "Book-length Translations by Langston Hughes" in his bio-bibliography of the poet. A third group of compilers include original works and translations made by the author in the same chapter, but making it explicit that both things have been included, in other words, emphasizing the difference. See, for instance Emily Mitchell Wallace (1968), whose first chapter is called "Books and Pamphlets written or translated by William Carlos Williams." And there is yet one more group of compilers that include translations made by the authors together with their original poetic works. For example, Donald Gallup (1953 [1947]) gathers poetry, criticism and translations made by T. S. Eliot under the title "Books and Pamphlets by T. S. Eliot."

\footnotetext{
18 “quien, a su vez, tradujo varios de sus poemas al español y escribió luminosas páginas sobre el sentido de su obra" (Obra poética, 2008, back cover).
} 


\subsection{Two special cases of Modernist poet-translators}

There are two Modernist poets whose role as translators especially relevant. They are Hilda Doolittle, who published under the initials H.D., and Ezra Pound. H.D. translated ancient Greek poetry throughout her career. Her translations published in book-format appear in H.D. A Bibliography, 1905-1990, compiled by Michael Boughn (1993), in the chapter called "Books, Pamphlets, and Broadsides," together with the rest of H.D.'s original creations.

Let us look at two of these translations. The first one is Choruses from Iphigeneia in Aulis, published in Great Britain in 1916 in "The Poet's Translation Series." The title of the series reveals that the publisher, Ballantyne Press, considered translations made by poets as something special. That same year, the American publishing house The Clerk's Press issued that translation in the United States. The publisher's note reads: "Of the translation it is sufficient to say that it was made by a poet who has re-interpreted the spirit of the original. It has been highly praised in England..." (quoted in: Boughn 1993, 4). That is, nearly a century ago, the publishers of Choruses... already considered poetry translation as a re-interpretation of the original.

The second one is H.D.'s translation of Ion, by Euripides. It is an annotated translation published both in Great Britain and in the United States in 1937. World War II had a direct impact on the stored copies of the book. Out of the 1,000 printed copies, "200 in loose sheets were destroyed by German bombs in October 1940" (Boughn 1993, 5). In this case, the war's impact on the literary system was not metaphorical but tangible. Ion was republished nearly five decades later, in 1986, by Black Swan Books. The new corrected version had "the emendations H.D. then made in her copy of the 1937 printing (published by Chatto \& Windus)" (Boughn 1993, 34). Note that Black Swan Books changed its point of view regarding H.D.'s authorship. The publishers presented the North-American poet as the author of the theatrical play and stated on the cover: "A play after Euripides," stressing the original value of her translation, which here becomes an adaptation.

If we have a look at the poems originally written by Hilda Doolittle we will easily see the cultural inheritance of ancient Greece is present throughout her work, both in the topics of the poems and in the images used. Take, for instance, poems "Demeter," "Circe," or "Phaedra," included in Hymen (1921); or "And Pergamos," and "At Ithaca," published in Selected Poems (1957). Even the title of her work Palimpsest (1926) plays with the different layers of meaning 
and references that can be found in her poetry. In this case, translation could be considered both a source of inspiration and a way of approaching classical models referenced in her own poetry (see 3.3 of this paper).

Ezra Pound also translated many books during his career, mainly from Chinese, Japanese, and French literature, into English as well as into Italian. Among his translation are Dialogues of Fontenelle (1917), and Natural Philosophy of Love (1922), by Remy de Gourmont; The Call of the Road (1923), by French writer Edouard Estaunié; an adaptation of Sophocles's text Women of Trachis, and several books by Confucius, both into English and into Italian-Ta Hio (1928), Digest of the Analects (1937), Confucius. The Unwobbling Pivot \& The Great Digest (1947), Confucian Analects (1951), Testamento di Confucio (1944), ${ }^{19}$ and Ciung Iung. L'asse che non vacilla (1945).

However, his translations from Chinese and Japanese literature were a source of polemic, since they were mainly indirect translations based on someone else's notes and comments. Two of these translation collections, Cathay (1915), and Certain Noble Plays of Japan (1916), took as a starting point the work of Ernest Fenollosa, a North-American expert on Oriental art and culture based in Tokyo. In their title pages we can read- "Cathay. Translations by Ezra Pound for the most part from the Chines of Rihaku, from the notes of the late Ernest Fenollosa, and the decipherings of the professors Mori and Ariga" and "Certain Noble Plays of Japan: from the manuscripts of Ernest Fenollosa, chosen and finished by Ezra Pound."20

If that was the process he followed, why then are they included as original work by Pound? To what extent did the American poet contribute to the translations of Cathay and Certain Noble Plays of Japan? According to professor at Norhteastern University Andrew Karas (2010), and to scholar Hugh Kenner (1971), author of The Pound Era, Pound's job was praiseworthy, since he re-wrote the texts with the aim of introducing new models into the AngloSaxon repertoire. In that sense, they would agree with Even-Zohar's idea that, under certain circumstances, translated literature can "become one of the means of elaborating the new repertoire" (Even-Zohar 1990, 47), as already mentioned in the introduction to this paper.

\footnotetext{
19 “version italiana di Ezra Pound e di Alberto Luchini” (cover text quoted in: Gallup 1969, 97).

${ }^{20}$ Quoted in: Gallup 1969, 36, 43.
} 
In Karas's (2010) words:

Yet in writing the poems contained in Cathay, Pound set out to do much more than transcribe Chinese poems word-for-word or line-for-line into English. He set out to redefine poetic translation itself, replacing long-held ideals like 'accuracy' and 'faithfulness' with a conviction that one could use old — even ancient — texts to make English poetry look and sound quite new.

Although his allusion to "word-for-word" translation seems exaggerated, since that practice has long been forgotten, the important point here is the contrast drawn by Karas between an accurate and faithful translation - normally praised - and the free adaptation made by Pound in order to appropriate classic Chinese models and use them to make American literature new. Karas (2010) insists on this intention and agrees with Kenner that Pound changes or omits parts of the texts, "to produce innovative English poems using the ancient Chinese texts as an inspirational springboard, not a constraining template" (Karas 2010). Forty years earlier, Kenner $(1971,199)$ had been even more vehement_- "Its real achievement lay not on the frontier of comparative poetics, but securely within the effort, then going forward in London, to rethink the nature of an English poem."

The innovative value of Pound's translation, which was in reality an adaptationrecreation from classical Chinese poems, has led the publishing world to consider Cathay an original work by the North-American poet. That explains why we can find it translated into Greek, asKatai, 1979, 1997, and Poiimata, 1981; into Turkish, asCathay, 1987; into Italian, asCatai, 1995; intoJapanese, as Ooharai, 2005; and into Spanish, asCathay, 1972 and 1980, in this case translated by Ricardo Silva-Santisteban. Tusquets, the well-respected he publisher of the Spanish translation, justify the chained authorship with the following words:

This edition of Cathay arrives to us thanks to a 'set of mirrors' - poems by Li Po, called here by his Japanese name Rihaku, are variations from traditional Chinese topics; Ernest Fenollosa took them and re-created them, but left the poems unfinished; Ezra Pound conceived Cathay stemming from Fenollosa's work; and finally, Ricardo Silva Santisteban offers his Spanish version. Whose is Cathay? Let's say it is Pound's because he was the first who conceived the work as we can read it now. ${ }^{21}$

\footnotetext{
21 “Esta edición de Cathay nos llega por un 'juego de espejos': los poemas del poeta Li Po (que aquí aparece con el nombre japonés Rihaku) son variaciones sobre temas tradicionales chinos; Ernest Fenollosa los recogió y los re-creó dejándolos inacabados; Ezra Pound concibió el Cathay a partir del trabajo de Fenollosa; y finalmente, Ricardo Silva Santisteban da su versión española. ¿De quién es Cathay? Digamos que de Pound por haber sido el primero en concebirlo tal como hoy puede leerse" (cover text, Cathay, 1980 [1972]).
} 
This explains why Pound appears as author both on the cover and the title page.

In the introduction to that same edition, however, Mirko Lauer mentions the controversy around the "paternity" of the text: "We could assume that Pound's? signature under the text is due to a chronological criterion more than anything else; Fenollosa, Silva Santisteban or Rihaku himself could have the same right to be called authors of the book" (Lauer 1972, 7). ${ }^{22}$ Notice that among the rightful authors, Lauer also names the Spanish translator, stressing the conception of translator as writer promoted by Bassnett and Bush (2006).

\section{Conclusion}

In conclusion, poet-translators are quite common, at least as far as North-American Modernism and its translation into Spanish is concerned. Such a role can be found both among the translators of Modernist poetry books and anthologies, and among the Modernist poets themselves. As mentioned at the beginning of this article, poet-translators occupy two places inside the global literary system (as authors of their own creations, and as translators - or should we say coauthors? —of someone else's poems). Thanks to this task, poet-translators internationalize the original poets and introduce them into world literature, becoming a bridge between cultures. Jenaro Talens, Andrés Sánchez Robayna, or Jordi Doce are some examples of that kind of poettranslator. Octavio Paz, Juan Ramón Jiménez, Marianne Moore, Yvor Winters, Elizabeth Bishop, or H. D. would be examples of the second kind-the translated poet-translator.

The double link represented by poet-translators can be studied alongside another link, that of translators-anthologists. In the dynamic world of comparative literature, the role of translators as re-writers and co-authors of the translated text can be applied twice to translatoranthologists, since they often not only choose and translate the poems to be included in the new selection, but also tend to comment on them. That way, their creative role is enhanced to the extent that they are sometimes considered the authors of the anthology. That is the case of Argentinian poet Alberto Girri's anthology of Wallace Stevens poetry (Poemas de Wallace

\footnotetext{
22 "Es de suponer que la firma única de Pound en este caso corresponde más a un criterio cronológico que a uno real: con igual justicia y probabilidad podrá este libro llegar a ser de Fenollosa, Silva Santisteban, o del propio Rihaku” (Pound 1972, 7).
} 
Stevens). Girri appears as author on the cover of the book, whereas the author of the original poems is integrated into the title.

When commenting on the poem "Domination of Black" ("Dominio del negro" in Girri's version), dedicated to the experience of the senses and its reminiscences, the translatoranthologist says: "Each of these states of mind influences us, and at the same time, is influenced by us ... The voice that speaks in the poem (us), cannot be split from the thing described or witnessed."23 The same explanation could be applied to translation practice. Although our understanding and later re-writing depend on the original text, by "registering" it, by interpreting it, we are partly creating the text as well, to the extent that our voice, like the poem's, "cannot be split from the thing described or witnessed." And not by chance, Girri adds in between brackets that the voice speaking corresponds to the plural "us", since in his translated poem we can hear Stevens's echo, Girri's own voice, and that of the reader that repeats the poem.

Alberto Girri's example introduces a new category - the poet-translator-anthologist, who plays a triple role within the global literary system. And not only that, for the three links of the chain represented by Girri get joined with those represented by Stevens, as poet and as translator of French avant-garde poet Jean Le Roy, deceased during World War I. According to Cleghorn (2011, 266), Le Roy “is then given literary life again through Steven's translation.” And that is the point. Translation brings back to life the poets' voice and introduces them into the international arena, in this way enlarging the human chain that makes up the global literary system.

\section{References}

Abrams, Sam. 2008. "Prólogo". In Elizabeth Bishop, Obra poética, 7-14. Tarragona: Igitur. Bassnett, Susan, and Peter Bush (eds). 2006. The Translator as Writer. London, New York: Continuum.

Boughn, Michael. 1993. H.D. A Bibliography, 1905-1990. Charlottesville, London: University of Virginia Press.

\footnotetext{
23 “Cada uno de esos estados influye sobre nosotros y es, a su vez, influido por nosotros al registrarlo ... El que habla en el poema (nosotros), es inseparable de lo que describe o presencia.” (Girri 1967, 18-19).
} 
Casanova, Pascale. 2002. "Conseçration et accumulation de capital littéraire. La traduction comme échange inégal". Actes de la recherché en sciences sociales 144: 7-20.

Cleghorn, Angus. 2011. 'Stevens' Translated 'Moment of Light' from 1918: Refracting the Poet's Role.” The Wallace Stevens Journal 35 (2) (Fall): 266-277.

Donald C. Dickinson. 1972. A Bio-bibliography of Langston Hughes. Hamdem, Co.: Archon Books.

Even-Zohar, Itamar. 1990. "The Position of Translated Literature within the Literary Polysystem." Poetics Today, Polysystem Studies 11(1): 45-51.

Ferguson, Margaret, et al. (eds). 2004 [1970]. The Norton Anthology of Poetry. London, New York: W. W. Norton, $5^{\text {th }}$ ed.

Gallup, Donald. 1953 [1947]. T. S. Eliot. A Bibliography. New York: Harcourt, Brace and Co.

-. 1969. A Bibliography of Ezra Pound. London: Rupert Hart-Davis, The Chaucer Press.

Guillén, Claudio. 2005 [1985]. Entre lo uno y lo diverso. Introducción a la literatura comparada (Ayer y hoy). Barcelona: Tusquets, rev. ed.

Heilbron, Johan. 1999. "Towards a Sociology of Translation. Book Translations as a Cultural World System.” European Journal of Social Theory 2 (4): 429-444.

Karas, Andrew. 2010. "Cathay”. The Modernism Lab. New Haven (CT): Yale University, http://modernism.research.yale.edu/wiki/index.php/Cathay

Kenner, Hugh. 1971. The Pound Era. Berkeley, Los Angeles: University of California Press.

Lauer, Mirko. 1972. "Prólogo". In Ezra Pound, Cathay. Barcelona: Tusquets.

Lehman, David, y John Brehm (eds). 2006 [1976]. The Oxford Book of American Poetry. New York: Oxford University Press.

Malpartida, Juan, and Jordi Doce. 2001. “Introducción”. In T. S. Eliot, La tierra baldía. Cuatro cuartetos y otros poemas. Poesía selecta (1909-1942), 7-45. Barcelona: Círculo de Lectores.

Margarit, Joan. 2008. "Estudio preliminar”. In Elizabeth Bishop, Obra poética, 17-53. Tarragona: Igitur.

Mata Buil, Ana. 2016. La antología como carta de presentación de un poeta. Estudio del modernism norteamericano y propuesta de antología bilingüe de Edna St. Vincent Millay. $\mathrm{PhD}$ thesis. Barcelona: Universitat Pompeu Fabra.

Nelson, Cary (ed.). 2000. Anthology of Modern American Poetry. Oxford, New York, Athens, Auckland: Oxford University Press. 
Parisi, Joseph, and Stephen Young (eds). 2002. The Poetry Anthology. 1912-2002. Ninety Years of America's Most Distinguished Verse Magazine. Chicago: Ivan R. Dee.

Paz, Octavio. 1973. "La flor saxífraga” (intro.). In William Carlos Williams, Veinte poemas, 926. Mexico: Ediciones Era.

Powell, Grosvenor. 1983. Yvor Winters: An Annotated Bibliography 1919-1982. Metuchen, N. J., London: The Scarecrow Press.

Ramazani, Jahan, et al. (eds). 2003 [1973]. The Norton Anthology of Modern and Contemporary Poetry. London, New York: W. W. Norton, $3^{\text {rd }}$ ed.

Ruiz Casanova, José Francisco. 2007. Anthologos: poética de la antología poética. Madrid: Cátedra.

—. 2011. “¿Traductores-poetas o poetas-traductores?”. In José Francisco Ruiz Casanova, Dos cuestiones de literatura comparada: Traducción y poesía. Exilio y traducción, 93-118. Madrid: Cátedra.

Sapiro, Giséle. 2009. “L’Europe, centre du marché mondial de la traduction”. In Giséle Sapiro, L'Espace intellectuel en Europe: de la formation des États-nation à la mondialisation. XIXXXI siècle, 249-287. Paris: La Découverte.

Sela-Sheffy, Rakefet. 2005. "How to be a (recognized) translator". Target 17 (1): 1-26.

Wallace, Emily Mitchell. 1968. A Bibliography of William Carlos Williams. Middletown. Connecticut: Wesleyan University Press.

\section{Poetic works mentioned in the article}

Bishop, Elizabeth. 2008. Obra poética. Sam Abrams, and Joan Margarit (eds, trans). Tarragona: Igitur.

Eliot, T. S. 1946. Poemas. Dámaso Alonso, Leopoldo Panero, J. M. Muñoz Rojas, Charles D. Ley, and L. Cano (trans). Madrid: Editorial Hispánica.

—. 1954. Tierra baldía y otros poemas. Rodolfo Usigli, León Felipe, Octavio G. Barredo, B. Ortiz de Montellano, Juan Ramón Jiménez, Marià Manent, and Ángel Flores (trans). Buenos Aires: Los Grandes Poetas.

—. 2001. La tierra baldía. Cuatro cuartetos y otros poemas. Poesía selecta (1909-1942). Juan Malpartida, and Jordi Doce (selec, trans, intro). Barcelona: Círculo de Lectores.

Girri, Alberto. 1967. Poemas de Wallace Stevens. Buenos Aires: Bibliográfica Omeba. 
Moore, Marianne. 1967. The Complete Poems of Marianne Moore. New York: The Macmillan Co.

Pound, Ezra. 1972. Cathay. Ricardo Silva-Santisteban (trans). Barcelona: Tusquets, "Cuadernos marginales", 25.

Stevens, Wallace. 1980. Poemas. Andrés Sánchez Robayna (ed, trans). Barcelona: Plaza \& Janés.

—. 2003. De la simple existencia. Antología poética. Andrés Sánchez Robayna (ed, trans). Barcelona: Galaxia Gutenberg/Círculo de Lectores.

Williams, William Carlos. 1973. Veinte poemas, Octavio Paz (trans). México: Ediciones Era. 